\title{
Pengaruh Pemberian Tepung Biji Gamal (Gliricidia sepium) sebagai Pengganti Bungkil Kedelai dalam Ransum terhadap Kadar Hemoglobin dan Nilai Hematokrit Anak Babi Lepas Sapih
}

\author{
Hilarius Yosef Sikone ${ }^{\mathrm{a}}$, dan Gerson Frans Bira ${ }^{\mathrm{b}}$ \\ ${ }^{a}$ Fakultas Pertanian, Universitas Timor, Kefamenanu, TTU - NTT, 85613, Indonesia. \\ ${ }^{b}$ Fakultas Pertanian, Universitas Timor, Kefamenanu, TTU - NTT, 85613, Indonesia
}

\section{Article Info}

Article history:

Received 10 Agustus 2016

Received in revised form 15 September 2016

Accepted 19 September 2016

\section{Keywords:}

Tepung Biji Gamal

Bungkil Kedelai

Kadar Hemoglobin

Hematokrit

Anak Babi

\begin{abstract}
Abstrak
Upaya meningkatkan produktivitas ternak babi bisa melalui aspek pakan, karena pakan ternak babi merupakan salah satu faktor penting dalam usaha ternak babi. Tujuan penelitian ini adalah untuk mengetahui pengaruh pemberian tepung biji gamal (Gliricidia sepium) sebagai pengganti bungkil kedelai dalam ransum terhadap kadar hemoglobin $(\mathrm{Hb})$ dan hematokrit anak babi lepas sapih. Penelitian ini menggunakan dua belas ekor babi jantan peranakan VDL. Rancangan percobaan yang digunakan dalam penelitian ini adalah rancangan acak lengkap terdiri dari 3 perlakuan dan 4 ulangan. Ketiga perlakuan ransum yang dicobakan adalah: R0: Ransum tanpa campuran tepung biji gamal; R1: Ransum dengan tingkat pergantian tepung biji gamal terhadap bungkil kedelai sebesar 2,5\%.; dan R2: Ransum dengan tingkat pergantian tepung biji gamal terhadap bungkil kedelai sebesar $5 \%$.. Hasil penelitian menunjukkan bahwa penggun aan tepung biji gamal (Glicidia sepium) dalam pakan babi lepas sapih sebagai pengganti bungkil kedelai sampai dengan 2,5\% masih dapat ditolerir oleh anak babi, dengan kadar $\mathrm{Hb}$ dan nilai Hematokrit masih dalam kisaran normal, walaupun pada ternak babi tersebut menampakkan penampilan yang tidak baik. Lama perlakuan sangrai 15 menit diduga masih menunjukkan adanya aktivitas anti nutrisi pada ransum yang ditambahkan 2,5\% dan $5 \%$ tepung biji gamal. (22016 dipublikasikan oleh JAS.
\end{abstract}

\section{Pendahuluan}

Seiring dengan laju pertambahan penduduk yang terus meningkat, maka kebutuhan akan nilai gizi khususnya protein hewani terus meningkat pula Untuk memenuhi kebutuhan akan protein hewani bagi masyarakat, maka diperlukan adanya peningkatan pengelolaan dibidang peternakan. Ternak babi dapat diandalkan sebagai salah satu sumber pemenuhan protein asal hewan Usaha ini dapat memberikan hasil yang optimum jika dikelola secara modern dan professional. Artinya dalam mengusahakan ternak babi diperlukan manajemen pemeliharaan yang baik seperti; pakan, pemeliharaan kesehatan, perkandangan, bibit dan iklim yang menunjang.

Upaya meningkatkan produktivitas ternak babi bisa melalui aspek pakan, karena pakan ternak babi merupakan salah satu faktor penting dalam usaha ternak babi. Pakan yang memiliki kualitas maupun kuantitas yang optimum akan sangat mempercepat pertumbuhan babi. Pakan yang tepat atau memenuh syarat adalah penting akan tetapi relatif mahal, bahkan dapat mencapai 60 - 80 $\%$ dari seluruh pembiayaan usaha ternak babi (Ardana dan Harya Putra, 2008).

Tingginya biaya pakan pada ternak babi karena bahan penyusun ransumnya masih berkompetisi dengan kebutuhan manusia. Usaha yang ditempuh dalam memecahkan masalah ini adalah dengan jalan menggunakan atau memanfaatkan jenis pakan alternatif yang murah, mudah didapat dan ketersediaannya cukup serta tidak bersaing dengan manusia. Salah satu pakan potensial yang memenuhi syarat ketersediaannya adalah biji gamal (Gliricidia sepium), karena tanaman ini tersebar hampir diseluruh Indonesia dan di Nusa Tenggara Timur (NTT). Tanaman ini berkembang dengan baik terutama karena dijadikan sebagai tanaman penghijauan. Tanaman gamal memiliki nilai gizi yang cukup tinggi, dimana kandungan protein kasarnya sebesar 38,15\% (Tangendjaja et al., 1991). Walau demikian tanaman gamal memilik kelemahan yakni mempunyai kandungan anti nutrisi. Salah satu senyawa yang terkandung dalam daun dan biji gamal adalah komarin. Komarin mempunya sifat mudah larut dalam alkohol, khloroform, eter atau minyak ikan dan juga larut dalam alkali, serta pembentuk zat-zat mielotoksit yang cukup tinggi (Wina dan Syahgiar, 1991).

Faktor kesehatan ternak erat kaitannya dengan ketersediaan zat-za makanan dalam ransum, dimana bila ternak kekurangan salah satu atau sebagian dari zat-zat makanan yang diperlukan, maka ternak akan mengalam gangguan fungsi fisiologis tubuh. Darah adalah salah satu cairan tubuh yang sangat penting peranannya dalam kehidupan seekor ternak. Keberadaan darah didukung oleh ketersediaan zat-zat makanan dalam penyusunan ransumnya.

Agar dapat mencapai tingkat produktivitas ternak yang tinggi maka metabolisme dalam tubuh ternak harus berjalan seimbang. Indikatornya adalah dengan mengukur hemoglobin dan hematokritnya. Maka apabila hemoglobin darah tidak normal, akan terjadi anemia yang pada gilirannya dapa mengakibatkan kematian pada ternak. Dengan mengetahui kadar haemoglobin dan nilai hematokrit ternak, maka dapat diketahui pula status zat nutrisi dalam darah dan produktivitasnya. Namun informasi secara lengkap tentang aspek penggunaan biji gamal sebagai pakan alternatif terhadap kadar hemoglobin dan nilai hematokrit darah ternak babi belum banyak diteliti.

\section{Metode}

Penelitian ini telah dilaksanakan di Peternakan Babi milik bapak Thomas Hartanto desa Tapenpah kecamatan Insana selama 72 hari dengan masa penyesuaian 10 hari dan masa pengambilan data 62 hari $(9$ minggu). Ternak yang digunakan dalam penelitian ini adalah ternak babi jantan peranakan VDL sebanyak 12 ekor, dengan umur rata-rata 2 bulan dan rataan berat badan awa $8,475 \pm 0,915 \mathrm{~kg}$.

Peralatan yang digunakan adalah; timbangan berkapasitas $150 \mathrm{~kg}$ dengan kepekaan $0,5 \mathrm{~kg}$ merek Harmoni, untuk menimbang bobot badan ternak dan ransum. Timbangan berkapasitas $5 \mathrm{~kg}$, dan $2 \mathrm{~kg}$ merek Lion star, untuk menimbang ransum konsumsi dan sisa ransum setiap hari. Selain itu untuk pengambilan darah pada ternak babi menggunakan tabung venoject yang telah dilapisi EDTA didalamnya, jarum $5 \mathrm{Cm}$, alkohol dan kapas. Untuk pengukuran Hemoglobin darah $(\mathrm{Hb})(\mathrm{gram} / 100 \mathrm{ml}$ darah) digunakan spektrofotometer, pipet volumetric $5 \mathrm{ml}$, pipet $20 \mathrm{UI} /$ pipet Sahli, tabung reaksi dan larutan yang digunakan adalah Drabkins dan Siamethemoglobin standart. Untuk pengukuran Hematokrit (\% dari $100 \mathrm{ml}$ darah) menggunakan alat sentrifuge mikro hematokrit, tabung kapiler yang didalamnya telah dilapisi dengan EDTA dan skala pembacaan mikro hematokrit (Mulyadi, 1996).

Bahan makanan yang digunakan adalah; tepung jagung, dedak halus, tepung ikan, bungkil kedelai dan tepung biji gamal sebagai sumber protein alternative yang akan dicobakan serta premix. Perlakuan yang dicobakan dalam penelitian ini adalah 3 buah perlakuan yaitu: R0, R1, R2. Formula ransum dan kandungan nutrisi dari masing-masing perlakuan dapat dilihat dalam Tabel 1.

Tabel 1. Formula Ransum dan Perhitungan Kandungan Nutrisi Ransum.

\begin{tabular}{lccc}
\hline \multirow{2}{*}{ Bahan Makanan } & \multicolumn{3}{c}{ Perlakuan } \\
\cline { 2 - 4 } & $\mathrm{R} 0$ & $\mathrm{R} 1$ & $\mathrm{R} 2$ \\
\hline Tepung jagung kuning & 35 & 35 & 35 \\
Dedak halus & 48 & 48 & 48 \\
Tepung ikan & 5 & 5 & 5 \\
Bungkil keledai & 11,5 & 9 & 6,5 \\
Tepung biji gamal & - & 2,5 & 5 \\
Premix & 0,5 & 0,5 & 0,5 \\
\hline Jumlah & 100 & 100 & 100 \\
\hline \multirow{2}{*}{ Kandungan Nutrisi } & & & \\
& 17,31 & 17,18 & 17,05 \\
Protein kasar (\%) & 6,31 & 6,64 & 6,62 \\
Serat kasar (\%) & 2,84 & 2,85 & 2,85 \\
Lemak kasar (\%) & 0,72 & 0,67 & 0,67 \\
Ca (\%) & 1,28 & 1,24 & 1,24 \\
P (\%) & $2.584,14$ & $2.615,89$ & $2.647,64$ \\
Energi metabolis (kcal) & \multicolumn{3}{c}{} \\
\hline Keterangan: Protein kasar, serat kasar, lemak kasar, energi, Ca dan P, hasil analisa Laboratorium Kimia & \\
$\quad$ Pakan Fakultas Peternakan Undana Kupang (2016) &
\end{tabular}

Rancangan percobaan yang digunakan dalam penelitian ini adalah rancangan acak lengkap terdiri dari 3 perlakuan dan 4 ulangan. Ketiga perlakuan ransum yang dicobakan adalah

R0: Ransum tanpa campuran tepung biji gamal

R1: Ransum dengan tingkat pergantian tepung biji gamal terhadap bungkil kedelai sebesar $2,5 \%$

R2: Ransum dengan tingkat pergantian tepung biji gamal terhadap bungkil kedelai sebesar $5 \%$.

Variabel yang diamati sebagai indikator pengaruh perlakuan adalah jumlah kadar haemoglobin (gram/100ml darah) dan presentase nilai hematokrit (\% dari $100 \mathrm{ml}$ darah).

Data yang terkumpul dianalisis menurut prosedur analisis ragam (Analysis of Varience) dan jika terdapat pengaruh yang nyata pada taraf $5 \%$ dilanjutkan dengan uji Beda Nyata Terkecil (BNT) menurut petunjuk (Sugandi dan Sugiarto, 1994). Model matematika (RAL) adalah: $Y i j=\mu+\mathrm{Ti}+\sum \mathrm{ij}$ Dimana :

Yij : Hasil pengamatan perlakuan ke-I dan ulangan ke-j

$\mu \quad$ : Rata-rata umum perlakuan

Ti : Pengaruh perlakuan ke-i

$\sum$ ij : Eror perlakuan ke-i ulangan ke-j 


\section{Hasil dan Pembahasan}

\subsection{Pengaruh Perlakuan Terhadap Hemoglobin Darah Ternak Babi}

Hasil penelitian menunjukkan bahwa rata-rata hemoglobin $(\mathrm{Hb})(\mathrm{gram} /$ $100 \mathrm{ml}$ darah) darah ternak babi dari masing-masing ternak percobaan seperti terlihat pada Tabel 2 .

Tabel 2. Rata-rata Haemoglobin Ternak Babi Percobaan

\begin{tabular}{cc}
\hline Perlakuan & Rata-rata \\
R0 & $13,3 \pm 17(\mathrm{~b})$ \\
$\mathrm{R} 1$ & $10,5 \pm 0,25(\mathrm{a})$ \\
$\mathrm{R} 2$ & $9,6 \pm 0,46(\mathrm{a})$ \\
\hline Keterangan: Superskrip a, dan b yang berbeda dalam kolom yang sama menunjukkan perbedaan sangat \\
nyata $(\mathrm{P}<0,01)$.
\end{tabular}

Hasil analisis ragam menunjukkan bahwa perlakuan berpengaruh sangat nyata terhadap haemoglobin darah ternak babi $(\mathrm{P}<0,01)$. Hasil uji lanjutan dengan menggunakan uji Beda Nyata Terkecil (BNT) menunjukkan bahwa perlakuan R0 berbeda sangat nyata dengan R1 maupun R2 (P < 0,01). Sedangkan pada pasangan perlakuan R1-R2 tidak berbeda nyata $(\mathrm{P}>0,05)$.

Menurut Frandson (1992), bahwa kisaran haemoglobin darah ternak babi normal adalah 10-16 gram/100ml darah. Dari hasil Tabel 3 diatas terlihat bahwa kadar hemoglobin darah ternak babi percobaan untuk perlakuan R0 (kontrol) kadar $\mathrm{Hb}$ darahnya normal, 13,3 \pm 17 gram/100ml darah sedangkan untuk perlakuan R2 berada dibawah standar normal yakni 9,6 $\pm 0,46$ gram $/ 100 \mathrm{ml}$ darah. Untuk perlakuan R1 walaupun berada dalam batas standar normal, $10,5 \pm 0,25$ gram $/ 100 \mathrm{ml}$ darah namun menunjukkan adanya indikasi rendahnya kadar $\mathrm{Hb}$ darah seperti pada perlakuan $\mathrm{R} 2$. Walaupun jumlah $\mathrm{Hb} \mathrm{R} 1$ berbeda sangat nyata dengan R0 namun masih berada dalam kisaran standar normal.

Turunnya kadar $\mathrm{Hb}$ darah ternak babi perlakuan $\mathrm{R} 1$ pada batas standar normal dan pada R2 hingga dibawah standar normal tersebut diduga karena adanya zat antinutrisi (komarin) pada ransum sebanyak 2,5\% hingga 5\% dari total ransum yang diberikan menjadi penyebab terhambatnya proses metabolisme zat-zat gizi dan juga sebagai toksin yang dapat mengganggu proses pembentukan sel-sel darah merah. Koentjoko (2002), menjelaskan bahwa sifat antinutrisi adalah sebagai inhibitor (penghambat) proses metabolisme zat gizi dan sebagai "toksin" (racun) dimana dapat mengganggu proses pembentukan sel darah merah. Hal yang sama disampaikan pula oleh Hoffbrand dan Pettit (2000) bahwa sintesis hemoglobin yang terjadi dalam mitokondria oleh sederat reaksi biokimia dimulai dengan kondensasi glisin dan suksinil koenzim A dibawah aksi enzim kunci delta-amino laevulinic acid (ALA), akhirnya protoporfirin bergabung dengan besi untuk membentuk haem, yang masing-masing molekulnya bergabung dengan nilai rantai globin yang terbuat dari poliribosom. Proses ini sangat tergantung pada keseimbangan kandungan bahan penyusun ransum yang dikonsumsi oleh ternak.

Lebih lanjut dinyatakan pula oleh Ardana dan Harya Putra, (2008) bahwa pada keadaan dimana pembentukan darah kurang memadai karena gizi yang tidak baik, termasuk adanya defenisi zat besi, $\mathrm{Cu}$, vitamin dan asam-asam amino dalam makanan akan terjadi anemia. Hal lain yang menyebabkan turunnya kadar $\mathrm{Hb}$ darah pada perlakuan $\mathrm{R} 2$ adalah karena pengaruh sifat fisiologis ternak babi lepas sapih, dimana pada fase ini ternak babi berada pada kondisi kritis, karena antibodi yang berasal dari susu induk berkurang. Dalam hal ini seharusnya pakan anak babi dalam keadaan berkualitas tinggi dan berkeseimbangan zat gizi serta daya cernanya tinggi, bukan sebaliknya seperti yang dialami ternak babi perlakuan R2. Aritonang (1993), menyatakan bahwa ternak babi akan mengalami kondisi yang kritis pada fase setelah lepas sapih, karena anak babi telah dihentikan ketergantungannya pada susu induk yang kaya akan antibodi. Dalam hal ini maka semua keperluannya terutama makanan harus setara dengan kebutuhannya, berkualitas tinggi dan berkeseimbangan zat gizinya.

\subsection{Pengaruh Perlakuan Terhadap Nilai Hematokrit Darah Ternak Babi}

Rata-rata nilai hematokrit darah ternak babi percobaan dari masing-masing perlakuan dapat dilihat pada Tabel 3.

Tabel 3. Rata-rata Nilai Hematokrit Ternak Babi Percobaan

\begin{tabular}{cc}
\hline Perlakuan & Rata-rata \\
\hline R0 & $37,1 \pm 2,85(\mathrm{~b})$ \\
R1 & $33,4 \pm 1,38(\mathrm{a})$ \\
R2 & $29,9 \pm 0,85$ (a) \\
\hline Keterangan: Superskrip a dan b yag berbeda dalam kolom yang sama menunjukkan perbedaan yang sangat
\end{tabular}
nyata $(\mathrm{P}<0,01)$

Hasil analisis ragam menunjukkan bahwa perlakuan berpengaruh sangat nyata terhadap angka hematokrit darah ternak babi percobaan $(\mathrm{P}<0,01)$. Hasil uji lanjutan dengan menggunakan Uji Beda Nyata Terkecil (BNT) menunjukkan bahwa perlakuan R0 berbeda sangat nyata dengan R1 maupun R2 $(\mathrm{P}<0,01)$. Sedangkan pada pasangan perlakuan R1 $0 \mathrm{R} 2$ tidak berbeda nyata $(\mathrm{P}>0,05)$.

Menurut Schalm et al., (1975) bahwa angka hematokrit darah normal pada ternak babi berkisar antara $32-52 \%$ dengan rata-rata $42 \%$. Data pada Tabel 3 diatas terlihat bahwa angka hematokrit ternak babi percobaan untuk perlakuan R0 (kontrol) hematokritnya normal, 37,1 $\pm 2,86 \%$ sedangkan untuk perlakuan
R2 berada di bawah standar normal yaitu 29,6 $\pm 0,85 \%$. Untuk perlakuan R1 walaupun berada dalam standar normal, 33,3 $\pm 1,38 \%$ namun menunjukkan adanya indikasi rendahnya nilai hematokrit darah seperti pada perlakuan R2. Walaupun jumlah nilai hematokrit R1 berbeda sangat nyata dengan R0 namun masih berada dalam kisaran standar normal.

Variasi presentase nilai hematokrit dari tiap perlakuan sangat dipengaruhi oleh tingkat keberadaan zat antinutrien dalam ransum dan sifat fisiologis ternak babi lepas sapih, seperti halnya kadar haemoglobin darah. Dimana menurut Frandson (1992), bahwa nilai hematokrit dinyatakan sebagai presentase sel-sel darah merah dalam $100 \mathrm{ml}$ darah dan bahwa pada hewan normal angka hematokrit akan sebanding jumlah eritrosit dan kadar hemoglobinnya.

Turunnya presentase nilai hematokrit darah pada perlakuan R2 hingga dibawah standar normal diduga karena, pengaruh atau efek toksin dalam ransum yang mengandung zat-zat mielotoksit (komarin) sebanyak $5 \%$ dari total ransum yang diberikan sebagaimana pendapat Hughes-Jones dan Wickramasinghe (1995) bahwa penyebab gangguan pembentuksn sel darah merah antara lain; 1) defisiensi dari zat-zat hematinik esensial, 2) kelainan kronik, 3) infiltrasi sumsum tulang, 4) defisiensi endokrin, 5) zat-zat mielotoksit, anemia aplasia eritrosit murni. Hal lain yang menyebabkan turunnya presentase angka hematokrit tidak terlepas dari sofat fisiologis ternak babi lepas sapih itu sendiri.

Sedangkan pada perlakuan R0 presentase nilai hematokrit lebih tinggi dari pada R1-R2. Tingginya presentase nilai hematokrit darah ternak babi tersebut diduga karena pada perlakuan R0 tidak terdapat zat-zat mielotoksit sehingga tidak menyebabkan terganggunya proses pembentukan sel-sel darah merah. Dengan demikian fungsi penting dari sel-sel darah merah yakni; 1) mengangkut haemoglobin untuk mengenai jaringan dan untuk pertukaran gas yang baik, 2) menjaga haemoglobin dalam keadaan tereduksi, dan 3) mempertahankan keseimbangan osmotik dapat berjalan dengan baik (Hoffbrand dan Pettit, 2000).

\section{Simpulan}

Penggunaan tepung biji gamal (Glicidia sepium) dalam pakan babi lepas sapih sebagai pengganti bungkil kedelai sampai dengan $2,5 \%$ masih dapa ditolerir oleh anak babi, dengan kadar $\mathrm{Hb}$ dan nilai Hematokrit masih dalam kisaran normal, walaupun pada ternak babi tersebut menampakkan penampilan yang tidak baik. Lama perlakuan sangrai 15 menit diduga masih menunjukkan adanya aktivitas anti nutrisi pada ransum yang ditambahkan $2,5 \%$ dan $5 \%$ tepung biji gamal.

\section{Pustaka}

Ardana, I.B., Harya Putra, D.K., 2008. Ternak Babi. Manajemen Reproduksi, Produksi dan Penyakit. Udayana University Press, Denpasar.

Aritonang, D., 1993. Babi - Perencanaan Dan Pengelolaan Usaha. PT. Penebar Swadaya, Jakarta.

Frandson, R.D., 1992. Anatomi dan Fisiologi Ternak., Edisi ke-IV. ed. Gadja Mada University Press, Yogyakarta.

Hoffbrand, A.V., Pettit, J.E., 2000. Haematologi (Essential Haematology) Edisi ke-2. ed. Buku Kedoteran (EGC), Jakarta.

Hughes-Jones, N.C., Wickramasinghe, S.N., 1995. Haematologi (Catatan Kuliah), ke-5. ed. Buku Kedokteran (EGC), Jakarta.

Koentjoko, 2002. Nutrisi dan Pengelolaan Pakan Babi Tujuan Komersial.

Mulyadi, 1996. Petunjuk Pemeriksaan Darah Pada Ternak di Laboratorium Hematologi Balivet. Balai Penelitian Veteriner, Denpasar.

Schalm, O., W., Jain, N.C., Carrol, E.J., 1975. Veterinary Hematology, 3 rd ed, Lea and Febinger. Univ. Calif. Berkeley USA.

Sugandi, E., Sugiarto, 1994. Rancangan Percobaan, Teori dan Aplikasi. Andi Offset, Yogyakarta.

Tangendjaja, B., Parakkasi, E.A., Winugroho, M., 1991. Komposisi dan Sifat Kimia Daun Gamal.

Wina, E., Syahgiar, S., 1991. Gamal dan Pemanfaatannya. 